\title{
CACNA1S Gene
}

National Cancer Institute

\section{Source}

National Cancer Institute. CACNA1S Gene. NCI Thesaurus. Code C150193.

This gene plays a role in muscle cell membrane depolarization. 